\title{
Investigation of the Synergic Effect of the Colistin/ Sulbactam Combination in Carbapenem-Resistant Acinetobacter baumannii complex Strains with Time-Kill and Checkerboard Methods
}

\section{Karbapeneme Dirençli Acinetobacter baumannii complex Sușlarında Kolistin/Sulbaktam Kombinasyonunun Sinerjik Etkinlig̃inin Time-Kill ve Checkerboard Yöntemi ile Araștırılması}

İmdat KILBAȘ̣(IID), Hüseyin HATiPOG̃LU'(İD), Ümit KILIC̣'(İD), Elmas Pınar KAHRAMAN KILBAȘ (IID), Mehmet KÖROG̃LU'(IID), Mustafa ALTINDIȘ'(İD)

\footnotetext{
${ }^{1}$ Department of Medical Microbiology, Sakarya University Faculty of Medicine, Sakarya, Turkey

${ }^{2}$ Department of Medical Laboratory Techniques, Fenerbahçe University, Vocational School of Health Services, İstanbul, Turkey
}

\begin{abstract}
Introduction: Infections caused by carbapenem-resistant Acinetobacter strains have become very common in recent years, and the most frequently used medicinal treatment is colistin. Combination treatments should also be applied to prevent development of resistance to colistin. This study examines the in vitro synergic effect of the colistin/sulbactam combination in carbapenem-resistant Acinetobacter strains with the time-kill and checkerboard methods.
\end{abstract}

Materials and Methods: Twenty carbapenem-resistant Acinetobacter baumannii-calcoaceticus complex strains, which were isolated from various clinical samples, were included in this study. Strains were identified with mass spectrometry, and antibiotic sensitivity results were determined with the VITEK $2 \circledast$ system. The in vitro effect and synergic activity of the colistin, sulbactam, and colistin/ sulbactam combination on the carbapenem-resistant strains were determined using the time-kill and checkerboard methods. Seventeen strains were examined with the time-kill method, and twenty strains were examined using the checkerboard method. The fractional inhibitory concentration index of strains was calculated for detection of synergic effect.

Results: Using the time-kill method applied on the colistin/sulbactam combination showed that the combination had a synergic effect on all 17 strains, while sulbactam alone did not have a bactericidal effect in the studied concentrations. When applying the checkerboard method, it was determined that the colistin/sulbactam combination had a synergic effect on 17 of the strains (85\%) and an additive effect on 3 strains (15\%), sulbactam had a low effect alone (15\%), and colistin was effective on all strains.

Conclusion: Study results indicated that the colistin/sulbactam combination had a high level of synergic effect on all studied strains using both methods.

Key Words: Acinetobacter baumannii, Colistin, Sulbactam, Synergy, Time-kill, Checkerboard

Received/Geliș Tarihi: 22/07/2020 - Accepted/Kabul Ediliș Tarihi: 05/12/2020

${ }^{\oplus}$ Copyright 2021 by Flora. Available on-line at www.floradergisi.org. 


\title{
ÖZ \\ Karbapeneme Dirençli Acinetobacter baumannii complex Sușlarında Kolistin/Sulbaktam Kombinasyonunun Sinerjik Etkinlig̃inin Time-Kill ve Checkerboard Yöntemi ile Araștırılması
}

\author{
İmdat KILBAȘ', Hüseyin HATiPOG̃LU', Ümit KILIC̣1, Elmas Pınar KAHRAMAN KILBAȘ², \\ Mehmet KÖROG̃LU', Mustafa ALTINDIȘI \\ ${ }^{1}$ Sakarya Üniversitesi Tıp Fakültesi, Tıbbi Mikrobiyoloji Anabilim Dalı, Sakarya, Türkiye \\ 2 Fenerbahçe Üniversitesi, Sag̃lık Hizmetleri Meslek Yüksekokulu, Tıbbi Laboratuvar Teknikleri Programı, İstanbul, Türkiye
}

Giriş: Karbapenem dirençli Acinetobacter suşlarının neden olduğu infeksiyonlar son yıllarda çok yaygın hale gelmiştir ve en sık kullanılan tıbbi tedavi kolistindir. Kolistin direncinin gelişmesini önlemek için kombinasyon tedavileri de uygulanmalıdır. Bu çalışma karbapenem dirençli Acinetobacter suşlarındaki kolistin/sulbaktam kombinasyonunun in vitro sineriik etkisini zaman öldürme ve dama tahtası yöntemleriyle incelemektedir.

Materyal ve Metod: Çeşitli klinik örneklerden izole edilen yirmi karbapenem dirençli Acinetobacter baumannii-calcoaceticus kompleks suşu bu çalışmaya dahil edilmiştir. Suşlar kütle spektrometrisi ile tanımlanmış ve antibiyotik duyarlıık sonuçları VITEK 2® sistemi ile belirlenmiştir. Karbapenem dirençli suşlar üzerinde kolistin, sulbaktam ve kolistin/sulbaktam kombinasyonunun in vitro etkisi ve sinerjik aktivitesi, zaman öldürme ve dama tahtası yöntemleri kullanılarak belirlenmiştir. 17 suş zaman öldürme yöntemi ile incelendi ve yirmi suş da dama tahtası yöntemi kullanılarak incelendi. Suşların fraksiyonel inhibitör konsantrasyon indeksi sinerjik etkinin saptanması için hesaplanmıştır.

Bulgular: Kolistin/sulbaktam kombinasyonu üzerine uygulanan zaman öldürme yönteminin kullanılması, kombinasyonun 17 suşun tümü üzerinde sinerjik bir etkiye sahip olduğunu, ancak sulbaktamın sadece incelenen konsantrasyonlarda bakterisidal bir etkiye sahip olmadığını gösterdi. Dama tahtası yöntemini uygularken, kolistin/sulbaktam kombinasyonunun suşların 17 'sinde sinerjik bir etki (\%85) ve 3 suşta (\%15) ilave bir etkiye sahip olduğu, sulbaktamın tek başına düşük bir etkiye (\%15) sahip olduğu belirlenmiştir ve kolistin tüm suşlarda etkiliydi.

Sonuç: Çalışma sonuçları, kolistin/sulbaktam kombinasyonunun her iki yöntem kullanılarak incelenen tüm suşlar üzerinde yüksek düzeyde sineriik etkiye sahip olduğunu göstermiştir.

Anahtar Kelimeler: Acinetobacter baumannii; Kolistin; Sulbaktam; Sinerji; Time-kill; Checkerboard

\section{INTRODUCTION}

Infections caused by the Acinetobacter spp. species, referred to as opportunistic infections, have become more widespread in recent years. Acinetobacter species cause various infections, including ventilator-associated pneumonia, bacteremia, meningitis, catheter-related bloodstream infections, urinary tract infections, and surgical area infections $^{[1-3]}$. The ability of Acinetobacter species to survive in contained areas for long periods depends on its resistance to heat and $\mathrm{pH}$ fluctuations, as well as external environmental conditions $^{[2,4,5]}$. These characteristics pave the way for outbreaks through intensive care personnel or materials of common use.

Acinetobacter spp. isolates are resistant to many antibiotics, as they have plasmids, transposons, and integrons, which include genes resistant to different antibiotics, low outer membrane per- meability for some antibiotics, and efflux pum$\mathrm{ps}^{[6]}$. Another concern about Acinetobacter spp. is they rapidly develop resistance and, thus, lead to resistance to multiple drug- resistant strains. Resistance can also develop to carbapenem group antibiotics, one of the most important treatment alternatives for these infections. These issues present challenges in the treatment of Acinetobacter infections ${ }^{[2,7,8]}$. The most common, most important, and last alternative drug in treatment for these infections in recent years has been colistin (Polymyxin E) ${ }^{[9]}$. Despite its side effects, colistin is used in treatment today due to the lack of alternative options ${ }^{[10]}$. However, it is recommended to avoid using colistin alone to treat these infections; combination treatments are preferred to prevent development of resistance ${ }^{[11,12]}$. The presence of Acinetobacter strains, which are also resistant to colistin as observed in recent years, points to the importance of these combination treatments ${ }^{[13,14]}$. 
Various studies in the literature documented research on the synergic effect of various antibiotic combinations with colistin against Acinetobacter strains ${ }^{[10,15-18]}$; a few in vitro studies have examined the synergic effect of the colistin/sulbactam combination using various methods (time-kill, checkerboard, prediffusion, and E-test, to name a few) ${ }^{[14,18-20]}$. This study involves an examination of the synergic effect of the colistin/sulbactam combination on Acinetobacter baumannii/calcoaceticus complex strains, isolated from various clinical samples, which are also resistant to carbapenem group antibiotics, using the time-kill and checkerboard methods.

\section{MATERIALS and METHODS}

\section{Identification and Antibiotic Sensitivity of Strains}

Twenty Acinetobacter baumannii/calcoaceticus complex strains resistant to carbapenem group antibiotics, isolated from various clinical samples sent to Sakarya University Training and Research Hospital Medical Microbiology Laboratory, were included in this study. Samples were collected between January 2016 and May 2017. 8 samples were obtained from chest diseases, 6 from internal medicine, 1 from infectious diseases, 1 from surgery and 4 from the intensive care unit. The identification testing of the isolates was carried out using matrix-assisted laser desorption ionisation time of flight mass spectrometry (VITEK MS, bioMerieux, Marcy l'Etoile, France). Antimicrobial susceptibility tests were analysed using the VITEK $^{\circledR} 2$ automated system (bioMerieux, Marcy l'Etoile, France) (Table 1).

\section{Time-kill method}

Seventeen carbapenem-resistant Acinetobacter baumannii/calcoaceticus complex strains were studied with the time-kill method. Mueller Hinton Broth (MHB) was used for antibiotic dilution in tubes, and Mueller Hinton Agar (MHA) was used

\begin{tabular}{|c|c|c|c|c|c|c|c|c|c|c|c|c|c|c|c|c|c|}
\hline Strain & CS & IPM & MEM & FEP & TET & TZP & GM & SXT & AMP & AMC & AMi & CAZ & TGC & CIP & LEV & SAM & SFP \\
\hline 1 & $S$ & $\mathrm{R}$ & $\mathrm{R}$ & $\mathrm{R}$ & $\mathrm{R}$ & $\mathrm{R}$ & $S$ & $\mathrm{R}$ & $\mathrm{R}$ & $\mathrm{R}$ & $\mathrm{R}$ & $\mathrm{R}$ & - & $\mathrm{R}$ & $\mathrm{R}$ & - & - \\
\hline 2 & $S$ & $\mathrm{R}$ & $\mathrm{R}$ & - & $\mathrm{R}$ & $\mathrm{R}$ & $\mathrm{R}$ & $\mathrm{R}$ & $\mathrm{R}$ & $\mathrm{R}$ & $\mathrm{R}$ & $\mathrm{R}$ & $S$ & $\mathrm{R}$ & $\mathrm{R}$ & $\mathrm{R}$ & $\mathrm{R}$ \\
\hline 3 & $S$ & $\mathrm{R}$ & $\mathrm{R}$ & $\mathrm{R}$ & $\mathrm{R}$ & $\mathrm{R}$ & $S$ & $\mathrm{R}$ & $\mathrm{R}$ & $\mathrm{R}$ & $S$ & $\mathrm{R}$ & 1 & $\mathrm{R}$ & $\mathrm{R}$ & $\mathrm{R}$ & $\mathrm{R}$ \\
\hline 4 & $S$ & $\mathrm{R}$ & $\mathrm{R}$ & $\mathrm{R}$ & - & $\mathrm{R}$ & $S$ & $\mathrm{R}$ & $\mathrm{R}$ & $\mathrm{R}$ & $S$ & $\mathrm{R}$ & $S$ & $\mathrm{R}$ & - & $\mathrm{R}$ & $\mathrm{R}$ \\
\hline 5 & $S$ & $\mathrm{R}$ & $\mathrm{R}$ & $\mathrm{R}$ & $\mathrm{R}$ & $\mathrm{R}$ & $\mathrm{R}$ & $\mathrm{R}$ & - & - & $\mathrm{R}$ & $\mathrm{R}$ & 1 & $\mathrm{R}$ & $\mathrm{R}$ & $\mathrm{R}$ & $\mathrm{R}$ \\
\hline 6 & $S$ & $\mathrm{R}$ & $\mathrm{R}$ & $\mathrm{R}$ & $\mathrm{R}$ & $\mathrm{R}$ & $S$ & $S$ & - & - & $\mathrm{R}$ & $\mathrm{R}$ & - & $\mathrm{R}$ & 1 & $\mathrm{R}$ & $\mathrm{R}$ \\
\hline 7 & $S$ & $\mathrm{R}$ & $\mathrm{R}$ & $\mathrm{R}$ & $\mathrm{R}$ & $\mathrm{R}$ & $S$ & $S$ & - & - & $S$ & $\mathrm{R}$ & 1 & $\mathrm{R}$ & $\mathrm{R}$ & $\mathrm{R}$ & $\mathrm{R}$ \\
\hline 8 & $S$ & $\mathrm{R}$ & $\mathrm{R}$ & $\mathrm{R}$ & $\mathrm{R}$ & $\mathrm{R}$ & $\mathrm{R}$ & $\mathrm{R}$ & - & - & $\mathrm{R}$ & $\mathrm{R}$ & - & $\mathrm{R}$ & $\mathrm{R}$ & - & - \\
\hline 9 & $S$ & $\mathrm{R}$ & $\mathrm{R}$ & $\mathrm{R}$ & $\mathrm{R}$ & $\mathrm{R}$ & $\mathrm{R}$ & $\mathrm{R}$ & $\mathrm{R}$ & $\mathrm{R}$ & 1 & $\mathrm{R}$ & - & $\mathrm{R}$ & - & - & - \\
\hline 10 & $S$ & $\mathrm{R}$ & $\mathrm{R}$ & $\mathrm{R}$ & - & $\mathrm{R}$ & $\mathrm{R}$ & $\mathrm{R}$ & $\mathrm{R}$ & $\mathrm{R}$ & $S$ & $\mathrm{R}$ & - & $\mathrm{R}$ & - & - & - \\
\hline 11 & $S$ & $\mathrm{R}$ & $\mathrm{R}$ & $\mathrm{R}$ & I & $\mathrm{R}$ & $S$ & $\mathrm{R}$ & - & - & $S$ & $\mathrm{R}$ & $S$ & $\mathrm{R}$ & $\mathrm{R}$ & $\mathrm{R}$ & $\mathrm{R}$ \\
\hline 12 & $S$ & $\mathrm{R}$ & $\mathrm{R}$ & $\mathrm{R}$ & $\mathrm{R}$ & $\mathrm{R}$ & $\mathrm{R}$ & $\mathrm{R}$ & - & - & $S$ & $\mathrm{R}$ & $S$ & $\mathrm{R}$ & $\mathrm{R}$ & $\mathrm{R}$ & $\mathrm{R}$ \\
\hline 13 & $S$ & $\mathrm{R}$ & $\mathrm{R}$ & $\mathrm{R}$ & $S$ & $\mathrm{R}$ & $\mathrm{R}$ & $S$ & - & - & $\mathrm{R}$ & $\mathrm{R}$ & I & $\mathrm{R}$ & I & $\mathrm{R}$ & $\mathrm{R}$ \\
\hline 14 & $S$ & $\mathrm{R}$ & $\mathrm{R}$ & $\mathrm{R}$ & $S$ & $\mathrm{R}$ & $S$ & $\mathrm{R}$ & $\mathrm{R}$ & $\mathrm{R}$ & $\mathrm{R}$ & $\mathrm{R}$ & - & $\mathrm{R}$ & - & - & - \\
\hline 15 & $S$ & $\mathrm{R}$ & $\mathrm{R}$ & $\mathrm{R}$ & I & $\mathrm{R}$ & $S$ & $\mathrm{R}$ & - & $\mathrm{R}$ & $\mathrm{R}$ & $\mathrm{R}$ & I & $\mathrm{R}$ & $\mathrm{R}$ & $\mathrm{R}$ & $\mathrm{R}$ \\
\hline 16 & $S$ & $\mathrm{R}$ & $\mathrm{R}$ & $\mathrm{R}$ & $\mathrm{R}$ & $\mathrm{R}$ & $S$ & $\mathrm{R}$ & - & - & $S$ & $\mathrm{R}$ & $S$ & $\mathrm{R}$ & $\mathrm{R}$ & $\mathrm{R}$ & $\mathrm{R}$ \\
\hline 17 & $S$ & $\mathrm{R}$ & $\mathrm{R}$ & $\mathrm{R}$ & $\mathrm{R}$ & $\mathrm{R}$ & $\mathrm{R}$ & $\mathrm{R}$ & - & - & $S$ & $\mathrm{R}$ & $S$ & $\mathrm{R}$ & $\mathrm{R}$ & $\mathrm{R}$ & $\mathrm{R}$ \\
\hline 18 & $S$ & $\mathrm{R}$ & 1 & I & $\mathrm{R}$ & $\mathrm{R}$ & $\mathrm{R}$ & $\mathrm{R}$ & - & - & $\mathrm{R}$ & $\mathrm{R}$ & $S$ & $\mathrm{R}$ & $\mathrm{R}$ & $\mathrm{R}$ & $S$ \\
\hline 19 & $S$ & 1 & $\mathrm{R}$ & $S$ & I & I & $S$ & $S$ & - & - & $S$ & $S$ & $S$ & $\mathrm{R}$ & I & $\mathrm{R}$ & $S$ \\
\hline 20 & $S$ & $\mathrm{R}$ & $\mathrm{R}$ & $\mathrm{R}$ & $\mathrm{R}$ & $\mathrm{R}$ & $\mathrm{R}$ & $\mathrm{R}$ & _ & _ & $\mathrm{R}$ & $\mathrm{R}$ & $S$ & $\mathrm{R}$ & $\mathrm{R}$ & $\mathrm{R}$ & 1 \\
\hline
\end{tabular}


for viable count. Bacterial suspension was configured to the $0.5 \mathrm{McF}$ arland standard with the photometric method for every strain, so the final bacterial count was adjusted to $1 \times 10^{5} \mathrm{cfu} / \mathrm{mL}$.

Antibiotic (colistin and sulbactam) MHB was prepared in concentrations two times high and two times low than the MIC value in current Clinical \& Laboratory Standards Institute (CLSI) standards for colistin and sulbactam. For the final concentration, the first tubes were prepared to include $8 \mu \mathrm{g} / \mathrm{mL}$ colistin $(4 \mathrm{x}-\mathrm{MIC}), 16 \mu \mathrm{g} / \mathrm{mL}$ sulbactam (4x-MIC), and $8 \mu \mathrm{g} / \mathrm{mL}$ colsitin $+16 \mu \mathrm{g} /$ $\mathrm{mL}$ sulbactam, and the tubes were held subject to serial dilution. Every tube received a transfer of $100 \mu \mathrm{L}$ bacteria from the bacteria suspension and left for incubation at $35-37^{\circ} \mathrm{C}$. Right before the start of incubation ( 0 hour), $100 \mu \mathrm{L}$ from each concentration of antibiotics and the control tube was transferred to the first tube, which included $900 \mu \mathrm{L} \mathrm{0.09 \%}$ saline solution, and the other tubes (remaining 5) were held subject to serial dilution. Bacteria+antibiotic suspension was taken with $0.001 \mathrm{~mL}$ single use standard loop from every tube after serial dilution and cultured in the MHA. The same process was repeated at $3,6,12$, and 24 hours. Reproduction in the passages in the MHA was evaluated after 16-18 hours of incubation at $35-37^{\circ} \mathrm{C}$. If reproduction was present, the number of colonies was recorded. Taken into account were 30-300 with colony reproduction of the plates from six dilutions. When less than 30 reproductions were identified in all six plates, the number of colonies in the dilution free plate or the number of colonies in the plate from the first dilution was taken into account $^{[21,22]}$.

If there was $3 \log _{10}$ and higher reduction in the bacteria count in the reading periods compared to the initial dilution $\left(1 \times 10^{5}\right)$, it was the bactericidal effective concentration of the antibiotic in the respective reading period. The numbers of colonies in every antibiotic concentration and reading period for every strain were logarithmically recorded.

\section{Checkerboard Method}

As a result of the calculations made according to the MICs of antibiotics for the study; $1 \mathrm{mg}$ colistin, $62.5 \mathrm{~mL}$ and $1 \mathrm{mg}$ sulbactam were diluted with $7.8 \mathrm{~mL}$ MHB $(16 \mu \mathrm{g} / \mathrm{mL}, 128 \mu \mathrm{g} / \mathrm{mL})$. $1 \mathrm{~mL}$ of each dilution was taken and subjected to serial dilution in tubes containing $1 \mathrm{ml} \mathrm{MHB}$. $100 \mu \mathrm{L}$ of each of these prepared dilution tubes were pipetted into the wells in the microplate. Later; The bacterial suspension prepared in MHB

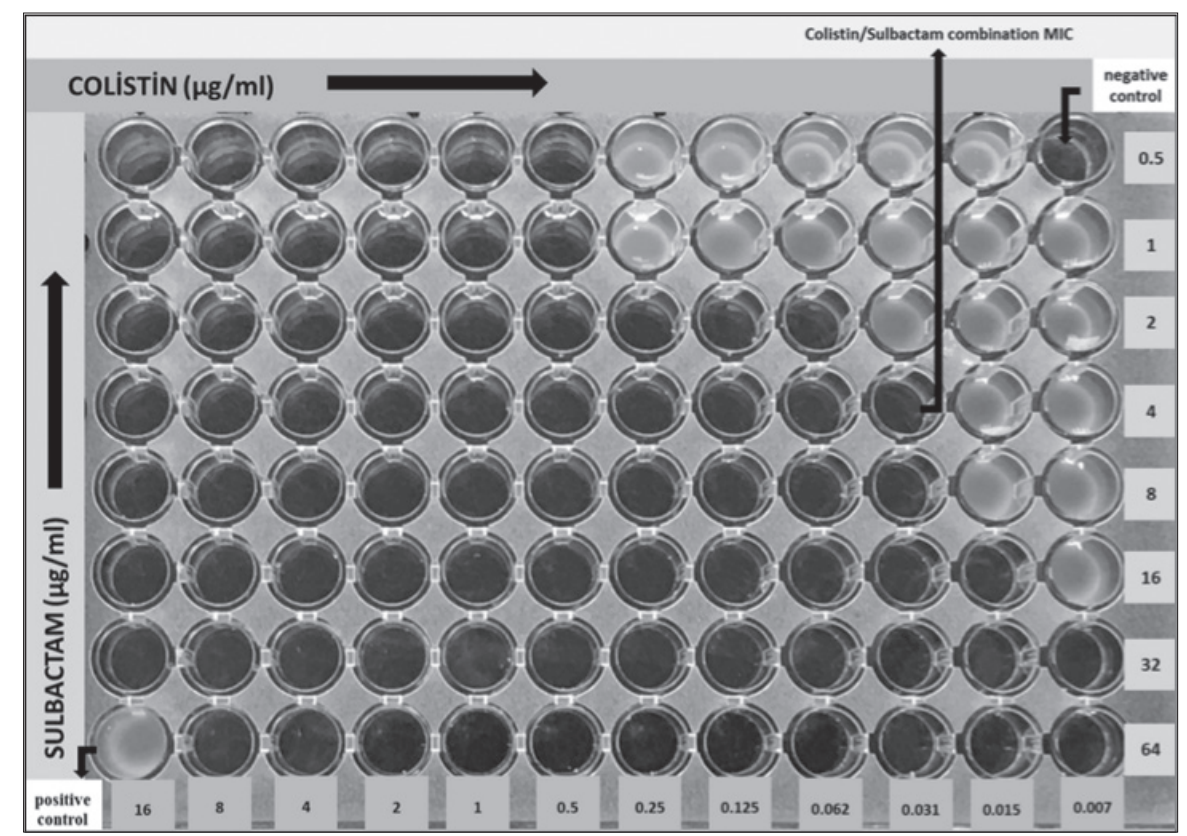

Figure 1. Colistin/sulbactam combination synergy study with checkerboard method. 
was adjusted to $0.5 \mathrm{McF}$ arland standard by photometric method, diluted $1 / 30$ and $10 \mu \mathrm{L}$ of this bacterial suspension was added to all wells in the microplate ${ }^{[37]}$. The results were evaluated after $18-20$ hours of incubation at $35-37^{\circ} \mathrm{C}$. MIC values of each strain were determined for colistin and sulbactam. MIC studies of 8 strains were performed in each microplate.

One microplate was used for combination/ synergy (colistin + sulbactam) study with each strain. For the colistin and sulbactam combination study, $50 \mu \mathrm{L}$ of the colistin dilutions were placed in microplate wells before the $1 \mathrm{~mL}$ antibiotic tubes, dilutions of which were prepared as described above. Colistin concentration in the microplate was adjusted from left to right in such a way that the titers gradually decreased. Then, $50 \mu \mathrm{L}$ was added with increasing sulbactam concentration from top to bottom (A-B-C-D direction). Except for the negative control (sterility control) well, $10 \mu \mathrm{L}$ of the bacterial suspension was added to all the wells in the microplate and incubated. Colistin and sulbactam MIC values were determined under combination conditions after incubation. While evaluating the synergistic effect in the study, it was evaluated using the methods determined by the Clinical and Laboratory Standards Institute $(\mathrm{CLSI})^{[23]}$.

\section{Determination of Synergy}

Using the checkerboard method, the fractional inhibitory concentration index (FICI) of all strains was calculated as follows: $\mathrm{FICI}_{\mathrm{A} / \mathrm{B}}=\left(\mathrm{MIC}_{\mathrm{A} \text { (combi- }}\right.$ nation $\left.) / \mathrm{MIC}_{\mathrm{A} \text { (alone) }}\right)+\left(\mathrm{MIC}_{\mathrm{B} \text { (combination) }} / \mathrm{MIC}_{\mathrm{B} \text { (alo- }}\right.$ ne). According to accepted criteria, the result of FICIA/B was recorded for each strain as follows: $\leq 0.5$, synergy; > 0.5- $\leq 1$, additivity; $>1-\leq 4$, indifference; and $>4$, antagonism ${ }^{[20,24]}$.

Using the time-kill method, $3 \log _{10}$ and/or more reduction in the bacteria count in the same dilution and at the same hour compared to the colistin/sulbactam combination and colistin alone was evaluated as synergic.

\section{Ethical Assessment}

Approval was obtained from Sakarya University Faculty of Medicine Deanery Non-invasive Ethics Committee for our study.

\section{RESULTS}

A bactericidal effect was identified in all 17 strains on which the colistin/sulbactam combination synergic effect was studied with the time-kill method. In addition to 17 isolates studied with the Time Kill method, 3 strains isolated later on were studied only with the Checkerboard method due to technical inadequacies. Using the time-kill method, synergy was determined in 15 isolates (88.3\%) at 3 hours and in 13 isolates (76.4\%) at 12 hours in $\mathrm{MIC} / 2$ dilution. Colistin was the most effective at 6 hours. Bactericidal effect was observed in some reading periods, even in the colistin MIC/2 concentration. The $\log _{10}$-based colony numbers of colistin, sulbactam and colistin sulbactam according to the incubation times of 17 strains in the time kill method are given in Table 3 and Figure 2.

The MIC values of antibiotics alone and in combination in the strains included in the study determined with the checkerboard method are provided in Table 2. The colistin MIC value was lower than the values determined in the VITEK $2^{\circledR}$ automated system in three strains. Using this method, sulbactam alone was only effective on the MIC level $(8 \mu \mathrm{g} / \mathrm{mL})$ in 3 strains (15\%) with the checkerboard method. A synergistic effect was found in 17 (85\%) of 20 strains with the colistin/sulbactam combination. An additive effect was detected in $15 \%$ of the 3 strains with this method. The MIC mean value was $0.05 \pm 0.71$ for colistin and $4.6 \pm 3.11$ for sulbactam in the combination. In addition, MIC values and synergy findings also obtained with the checkerboard method and VITEK $2^{\circledR}$ system are summarised in Table 2.

\section{DISCUSSION}

Acinetobacter species are important pathogens that cause ventilator-associated pneumonia, bloodstream infections, and wound infections in immunosuppressed patients. Hospital infections caused by Acinetobacter spp. have gradually increased in recent years. Acinetobacter calcoaceticus-Acinetobacter baumannii (ACB) complex is the most frequent factor in this type of infection among Acinetobacter species. The most important problem in the treatment of these infections is that 
Table 2. MIC $(\mu \mathrm{g} / \mathrm{mL})$ and $\mathrm{FICl}$ values of colistin and sulbactam of strains with the checkerboard and time kill method synergy data

\begin{tabular}{|c|c|c|c|c|c|c|c|c|c|}
\hline \multirow[b]{2}{*}{ Strain } & \multirow{2}{*}{$\begin{array}{l}\text { VITEK } 2{ }^{\circledR} \\
\text { Colistin MIC }\end{array}$} & \multirow{2}{*}{$\begin{array}{l}\text { Colistin } \\
\text { MIC }\end{array}$} & \multirow{2}{*}{$\begin{array}{l}\text { Combination } \\
\text { Colistin MIC }\end{array}$} & \multirow{2}{*}{$\begin{array}{l}\text { Sulbactam } \\
\text { MIC }\end{array}$} & \multirow{2}{*}{$\begin{array}{l}\text { Combination } \\
\text { Sulbactam MIC }\end{array}$} & \multicolumn{2}{|c|}{ Synergy } & \multirow[b]{2}{*}{$\mathrm{FICl}$} & \multirow[b]{2}{*}{ Comment } \\
\hline & & & & & & Time Kill & Checkerboard & & \\
\hline 1 & 0.5 & 0.25 & 0.062 & 16 & 4 & + & + & 0.5 & Sinergy \\
\hline 2 & 0.5 & 0.5 & 0.125 & 16 & 4 & + & + & 0.5 & Sinergy \\
\hline 3 & 0.5 & 0.5 & 0.062 & 8 & 2 & + & + & 0.37 & Sinergy \\
\hline 4 & 0.5 & 0.5 & 0.015 & 32 & 4 & + & - & 0.56 & Additive \\
\hline 5 & 0.5 & 0.5 & 0.125 & 16 & 2 & + & + & 0.33 & Sinergy \\
\hline 6 & 0.5 & 0.25 & 0.031 & 16 & 2 & + & + & 0.13 & Sinergy \\
\hline 7 & 0.5 & 0.5 & 0.031 & 32 & 4 & + & + & 0.18 & Sinergy \\
\hline 8 & 0.5 & 0.5 & 0.015 & 8 & 4 & + & + & 0.5 & Sinergy \\
\hline 9 & 0.5 & 0.25 & 0.031 & 16 & 4 & + & + & 0.37 & Sinergy \\
\hline 10 & 0.5 & 0.5 & 0.031 & 32 & 4 & + & + & 0.18 & Sinergy \\
\hline 11 & 0.5 & 0.5 & 0.031 & 32 & 4 & + & + & 0.18 & Sinergy \\
\hline 12 & 0.5 & 0.5 & 0.062 & 16 & 4 & + & + & 0.37 & Sinergy \\
\hline 13 & 0.5 & 0.5 & 0.015 & 32 & 8 & + & + & 0.28 & Sinergy \\
\hline 14 & 0.5 & 0.5 & 0.031 & 16 & 4 & + & + & 0.31 & Sinergy \\
\hline 15 & 0.5 & 0.5 & 0.062 & 16 & 2 & + & + & 0.25 & Sinergy \\
\hline 16 & 0.5 & 0.5 & 0.31 & 8 & 4 & + & - & 0.56 & Additive \\
\hline 17 & 0.5 & 0.5 & 0.031 & 32 & 8 & + & + & 0.31 & Sinergy \\
\hline 18 & 0.5 & 0.5 & 0.015 & 32 & 16 & $\begin{array}{l}\text { Not } \\
\text { tested }\end{array}$ & - & 0.53 & Additive \\
\hline 19 & 0.5 & 0.5 & 0.031 & 16 & 4 & $\begin{array}{l}\text { Not } \\
\text { tested }\end{array}$ & + & 0.31 & Sinergy \\
\hline 20 & 0.5 & 0.5 & 0.031 & 16 & 4 & $\begin{array}{c}\text { Not } \\
\text { tested }\end{array}$ & + & 0.31 & Sinergy \\
\hline
\end{tabular}

FICI: Fractional inhibitory concentration index, MIC: Minimum inhibitory concentration.

If the total FIC index 0.5. it was evaluated as synergy, if $1<\mathrm{FIC}>0.5$ as additive. if $>1$ as antagonist effect (Çıkman et al. 2013).

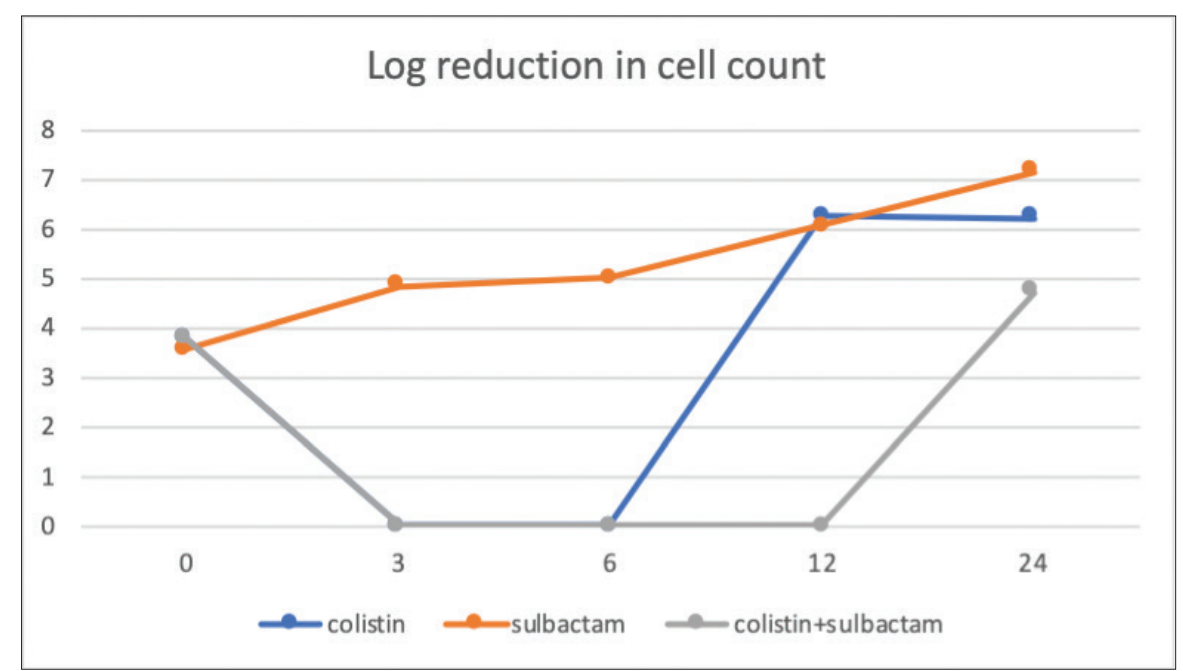

Figure 2. Change of $\log _{10}$-based colony numbers according to the incubation times of isolates in the time-killing method. 
Table 3. For 17 strains, $\log _{10}$ based colony numbers of colistin, sulbactam and colistin + sulbactam in Time Kill method according to incubation periods

\begin{tabular}{|c|c|c|c|c|c|c|c|c|c|c|c|c|c|}
\hline \multirow[b]{2}{*}{ Isolate no } & \multirow[b]{2}{*}{ Time } & \multicolumn{4}{|c|}{ Colistin } & \multicolumn{4}{|c|}{ Sulbactam } & \multicolumn{4}{|c|}{ Colistin + Sulbactam } \\
\hline & & $4 x$ & $2 x$ & $x$ & $x / 2$ & $4 x$ & $2 x$ & $x$ & $\mathrm{x} / 2$ & $4 x$ & $2 x$ & $x$ & $x / 2$ \\
\hline \multirow[t]{5}{*}{1} & 0. & 3.60 & 3.6 & 3.47 & 3.69 & 4.3 & 4.39 & 4.84 & 4.6 & 4 & 1.5 & 1.49 & 4 \\
\hline & 3. & 0 & 0 & 0 & 3.3 & 4.3 & 4.69 & 4.84 & 4.44 & 0 & 0 & 0 & 0 \\
\hline & 6. & 0 & 0 & 0 & 0 & 4.40 & 5 & 5.3 & 5.3 & 0 & 0 & 0 & 0 \\
\hline & 12. & 0 & 0 & 0 & 4.3 & 5 & 6.11 & 5.36 & 6.3 & 0 & 0 & 0 & 0 \\
\hline & 24. & 0 & 0 & 0 & 4.3 & 7.07 & 7.17 & 7.47 & 7.49 & 0 & 0 & 0 & 0 \\
\hline \multirow[t]{5}{*}{2} & 0. & 4.07 & 4.07 & 4.07 & 4.07 & 4.17 & 4 & 3.95 & 4.07 & 4.07 & 4.25 & 4.32 & 4.39 \\
\hline & 3. & 0 & 0 & 0 & 0 & 5.3 & 4.9 & 4.84 & 4.5 & 0 & 0 & 0 & 0 \\
\hline & 6. & 0 & 0 & 0 & 0 & 5.2 & 5.23 & 6.17 & 5.9 & 0 & 0 & 0 & 0 \\
\hline & 12. & 0 & 0 & 0 & 3 & 6.17 & 5.9 & 5.9 & 5.6 & 0 & 0 & 0 & 0 \\
\hline & 24. & 0 & 0 & 3.2 & 3.39 & 6.77 & 7.07 & 7.07 & 6.9 & 0 & 0 & 4.07 & 3.77 \\
\hline \multirow[t]{5}{*}{3} & 0. & 3.77 & 3.77 & 3.73 & 3.71 & 4.9 & 5.11 & 5.13 & 5.14 & 4.07 & 4.07 & 4.11 & 4.13 \\
\hline & 3. & 0 & 0 & 0 & 3.51 & 4.73 & 4.69 & 4.79 & 4.84 & 0 & 0 & 0 & 0 \\
\hline & 6. & 0 & 0 & 0 & 0 & 4.72 & 4.99 & 5.17 & 5.26 & 0 & 0 & 0 & 0 \\
\hline & 12. & 0 & 0 & 0 & 4.26 & 6.25 & 6.29 & 6.6 & 6.72 & 0 & 0 & 0 & 0 \\
\hline & 24. & 0 & 0 & 0 & 4.38 & 6.95 & 7.25 & 7.33 & 8.9 & 0 & 0 & 0 & 4.12 \\
\hline \multirow[t]{5}{*}{4} & 0. & 3.9 & 3.92 & 3.91 & 3.9 & 4.17 & 4.3 & 5.09 & 4.89 & 4.25 & 4.25 & 4.26 & 4.28 \\
\hline & 3. & 0 & 0 & 0 & 3.27 & 5.04 & 5.11 & 5.14 & 5.25 & 0 & 0 & 0 & 0 \\
\hline & 6. & 0 & 0 & 0 & 0 & 5 & 5.03 & 5.17 & 5.14 & 0 & 0 & 0 & 0 \\
\hline & 12. & 0 & 0 & 0 & 4.2 & 5.25 & 5.5 & 5.6 & 6.43 & 0 & 0 & 0 & 0 \\
\hline & 24. & 0 & 0 & 0 & 4.32 & 6.9 & 7.14 & 8.28 & 7.79 & 0 & 0 & 0 & 5.14 \\
\hline \multirow[t]{5}{*}{5} & 0. & 5.8 & 5.14 & 5.13 & 5.17 & 5.25 & 4.14 & 5.13 & 5.07 & 3.95 & 3.97 & 3.96 & 4.04 \\
\hline & 3. & 0 & 0 & 0 & 4.09 & 4.31 & 4.36 & 5.44 & 5.44 & 0 & 0 & 0 & 0 \\
\hline & 6. & 0 & 0 & 0 & 4.14 & 5.21 & 5.28 & 5.39 & 6.42 & 0 & 0 & 0 & 0 \\
\hline & 12. & 0 & 0 & 0 & 4.04 & 5.74 & 5.97 & 5.98 & 6.44 & 0 & 0 & 0 & 4.06 \\
\hline & 24. & 3.65 & 3.81 & 3.94 & 5.16 & 6.92 & 7.19 & 7.3 & 8.2 & 0 & 3.3 & 4.07 & 4.18 \\
\hline \multirow[t]{5}{*}{6} & 0. & 3.39 & 3.47 & 3.6 & 3.6 & 3.69 & 3.65 & 3.65 & 3.6 & 3.47 & 3.5 & 3.54 & 3.6 \\
\hline & 3. & 0 & 0 & 0 & 2.9 & 3.65 & 3.77 & 4.14 & 4.07 & 0 & 0 & 0 & 0 \\
\hline & 6. & 0 & 0 & 0 & 0 & 4 & 4.06 & 4.25 & 4.3 & 0 & 0 & 0 & 0 \\
\hline & 12. & 0 & 0 & 0 & 3.3 & 4.95 & 4.95 & 6.9 & 6.96 & 0 & 0 & 0 & 3.65 \\
\hline & 24. & 0 & 0 & 3.9 & 5.4 & 5.3 & 5.68 & 6.86 & 7.79 & 0 & 4.39 & 6.07 & 7.26 \\
\hline \multirow[t]{5}{*}{7} & 0. & 4 & 4.11 & 4.07 & 4.3 & 3.84 & 4.2 & 4.07 & 3.9 & 3.9 & 4 & 4 & 4.07 \\
\hline & 3. & 0 & 0 & 0 & 5.07 & 4.14 & 4.36 & 4.38 & 4.77 & 0 & 0 & 0 & 0 \\
\hline & 6. & 0 & 0 & 0 & 6.38 & 5.44 & 5.9 & 6.27 & 7.36 & 0 & 0 & 0 & 0 \\
\hline & 12. & 0 & 0 & 0 & 6.44 & 7.3 & 8.02 & 8.39 & 8.65 & 0 & 0 & 0 & 6.8 \\
\hline & 24. & 3.9 & 5.04 & 7.16 & 7.14 & 7.92 & 8.25 & 8.27 & 8.77 & 3.25 & 4.16 & 4.34 & 7.25 \\
\hline \multirow[t]{5}{*}{8} & 0. & 3.6 & 3.61 & 3.77 & 4 & 3.65 & 3.65 & 3.57 & 3.74 & 3.65 & 3.66 & 3.77 & 3.55 \\
\hline & 3. & 0 & 0 & 0 & 3.81 & 4.25 & 4.34 & 4.84 & 5.4 & 0 & 0 & 0 & 0 \\
\hline & 6. & 0 & 0 & 0 & 3.95 & 6.3 & 6.27 & 5 & 5.97 & 0 & 0 & 0 & 0 \\
\hline & 12. & 0 & 0 & 6.25 & 6.3 & 6.35 & 6.4 & 6.07 & 7.13 & 0 & 0 & 0 & 5.21 \\
\hline & 24. & 5.3 & 6.02 & 6.2 & 6.4 & 6.68 & 6.99 & 7.15 & 8.07 & 0 & 4.39 & 4.7 & 5.3 \\
\hline
\end{tabular}


Table 3. For 17 strains, $\log _{10}$ based colony numbers of colistin, sulbactam and colistin + sulbactam in Time Kill method according to incubation periods (continue)

\begin{tabular}{|c|c|c|c|c|c|c|c|c|c|c|c|c|c|}
\hline \multirow[b]{2}{*}{ Isolate no } & \multirow[b]{2}{*}{ Time } & \multicolumn{4}{|c|}{ Colistin } & \multicolumn{4}{|c|}{ Sulbactam } & \multicolumn{4}{|c|}{ Colistin + Sulbactam } \\
\hline & & $4 x$ & $2 x$ & $x$ & $x / 2$ & $4 x$ & $2 x$ & $x$ & $x / 2$ & $4 x$ & $2 x$ & $x$ & $x / 2$ \\
\hline \multirow[t]{5}{*}{9} & 0. & 3.6 & 3.54 & 3.57 & 3.69 & 3.6 & 3.69 & 3.64 & 3.69 & 3.5 & 3.73 & 3.6 & 3.85 \\
\hline & 3. & 0 & 0 & 0 & 0 & 4.2 & 4.25 & 4.44 & 4.63 & 0 & 0 & 0 & 0 \\
\hline & 6. & 0 & 0 & 0 & 0 & 5 & 5.04 & 5.14 & 5.25 & 0 & 0 & 0 & 0 \\
\hline & 12. & 0 & 0 & 0 & 3.9 & 5.07 & 5.25 & 5.69 & 5.92 & 0 & 0 & 0 & 0 \\
\hline & 24. & 0 & 0 & 3.44 & 4.25 & 5.59 & 5.99 & 6.83 & 7.06 & 0 & 0 & 0 & 3.27 \\
\hline \multirow[t]{5}{*}{10} & 0. & 4.44 & 4.43 & 4.38 & 4.38 & 4 & 4.07 & 3.9 & 4.07 & 4.07 & 4.07 & 3.95 & 3.84 \\
\hline & 3. & 0 & 0 & 0 & 3.15 & 4.34 & 4.39 & 4.45 & 4.91 & 0 & 0 & 0 & 0 \\
\hline & 6. & 0 & 0 & 0 & 4.14 & 5.25 & 5.36 & 5.39 & 5.39 & 0 & 0 & 0 & 0 \\
\hline & 12. & 0 & 0 & 0 & 5.22 & 5.6 & 5.81 & 6.07 & 6.84 & 0 & 0 & 0 & 0 \\
\hline & 24. & 0 & 0 & 5.3 & 6.34 & 5.95 & 6.84 & 6.97 & 8.14 & 0 & 0 & 4.17 & 5.25 \\
\hline \multirow[t]{5}{*}{11} & 0. & 3.6 & 3.51 & 3.54 & 3.6 & 4.07 & 3.5 & 3.51 & 3.69 & 3.95 & 3.6 & 3.6 & 3.47 \\
\hline & 3. & 0 & 0 & 0 & 0 & 4.34 & 4.44 & 4.54 & 4.65 & 0 & 0 & 0 & 0 \\
\hline & 6. & 0 & 0 & 0 & 3.6 & 4.69 & 5.25 & 5.27 & 5.3 & 0 & 0 & 0 & 0 \\
\hline & 12. & 0 & 0 & 0 & 4.07 & 4.54 & 4.94 & 7.87 & 7.9 & 0 & 0 & 0 & 0 \\
\hline & 24. & 0 & 0 & 5.14 & 7.03 & 7.25 & 7.3 & 8.65 & 8.71 & 0 & 0 & 5.07 & 7.03 \\
\hline \multirow[t]{5}{*}{12} & 0. & 4.17 & 4.25 & 4.29 & 4.3 & 4.07 & 4.09 & 4.11 & 4.16 & 3.84 & 3.81 & 3.85 & 3.84 \\
\hline & 3. & 0 & 0 & 0 & 3.65 & 4.16 & 4.3 & 5.39 & 5.99 & 0 & 0 & 0 & 0 \\
\hline & 6. & 0 & 0 & 0 & 4.19 & 5.9 & 6.27 & 6.95 & 7.11 & 0 & 0 & 0 & 0 \\
\hline & 12. & 0 & 0 & 0 & 4.26 & 5.95 & 7.25 & 6.92 & 7.04 & 0 & 0 & 0 & 0 \\
\hline & 24. & 0 & 0 & 4.86 & 5.65 & 6.95 & 6.96 & 7.01 & 7.3 & 0 & 0 & 3.54 & 4.07 \\
\hline \multirow[t]{5}{*}{13} & 0. & 3.95 & 4 & 3.97 & 3.69 & 3.77 & 3.9 & 3.84 & 3.92 & 3.84 & 3.95 & 3.87 & 4 \\
\hline & 3. & 0 & 0 & 0 & 0 & 4.25 & 4.38 & 5.39 & 6.16 & 0 & 0 & 0 & 0 \\
\hline & 6. & 0 & 0 & 0 & 0 & 4.92 & 6.25 & 6.92 & 7.14 & 0 & 0 & 0 & 0 \\
\hline & 12. & 0 & 0 & 0 & 5.26 & 5.92 & 6.28 & 7 & 7.2 & 0 & 0 & 0 & 0 \\
\hline & 24. & 0 & 0 & 4.16 & 6.43 & 5.94 & 6.98 & 8.01 & 8 & 0 & 0 & 3.61 & 5.71 \\
\hline \multirow[t]{5}{*}{14} & 0. & 3.68 & 3.65 & 3.7 & 3.57 & 3.94 & 4.06 & 4.14 & 4.12 & 3.57 & 3.69 & 3.72 & 3.77 \\
\hline & 3. & 0 & 0 & 0 & 0 & 4.14 & 4.38 & 4.82 & 5.04 & 0 & 0 & 0 & 0 \\
\hline & 6. & 0 & 0 & 0 & 0 & 5.09 & 6.3 & 6.39 & 6.73 & 0 & 0 & 0 & 0 \\
\hline & 12. & 0 & 0 & 0 & 0 & 5.17 & 6.14 & 6.31 & 6.27 & 0 & 0 & 0 & 0 \\
\hline & 24. & 0 & 0 & 0 & 3.97 & 6.18 & 6.14 & 6.99 & 7.03 & 0 & 0 & 3.27 & 4.94 \\
\hline \multirow[t]{5}{*}{15} & 0. & 3.65 & 3.69 & 3.86 & 3.85 & 4.19 & 4.16 & 4.2 & 4.27 & 4.16 & 4.17 & 4.18 & 4.25 \\
\hline & 3. & 0 & 0 & 0 & 0 & 4.3 & 4.46 & 5.3 & 5.25 & 0 & 0 & 0 & 0 \\
\hline & 6. & 0 & 0 & 0 & 0 & 4.68 & 4.9 & 5 & 5.07 & 0 & 0 & 0 & 0 \\
\hline & 12. & 0 & 0 & 0 & 3.92 & 5.49 & 5.9 & 6 & 6.13 & 0 & 0 & 0 & 0 \\
\hline & 24. & 0 & 0 & 3.46 & 4.76 & 5.77 & 7.14 & 7.21 & 7.3 & 0 & 0 & 3.98 & 4.79 \\
\hline \multirow[t]{5}{*}{16} & 0. & 3.99 & 4.07 & 4.12 & 4.15 & 4.07 & 3.89 & 4.03 & 3.94 & 4 & 3.5 & 3.49 & 3.69 \\
\hline & 3. & 0 & 0 & 0 & 4.07 & 4.34 & 4.44 & 4.54 & 4.65 & 0 & 0 & 0 & 0 \\
\hline & 6. & 0 & 0 & 0 & 3.54 & 4.69 & 5.25 & 5.27 & 5.34 & 0 & 0 & 0 & 0 \\
\hline & 12. & 0 & 0 & 0 & 4.99 & 4.54 & 5.97 & 6.69 & 6.9 & 0 & 0 & 0 & 0 \\
\hline & 24. & 0 & 3.23 & 4.65 & 5.27 & 7.25 & 7.3 & 7.65 & 8 & 0 & 0 & 3 & 3.74 \\
\hline
\end{tabular}


Table 3. For 17 strains, $\log _{10}$ based colony numbers of colistin, sulbactam and colistin + sulbactam in Time Kill method according to incubation periods (continue)

\begin{tabular}{|c|c|c|c|c|c|c|c|c|c|c|c|c|c|}
\hline \multirow[b]{2}{*}{ Isolate no } & \multirow[b]{2}{*}{ Time } & \multicolumn{4}{|c|}{ Colistin } & \multicolumn{4}{|c|}{ Sulbactam } & \multicolumn{4}{|c|}{ Colistin + Sulbactam } \\
\hline & & $4 x$ & $2 x$ & $\mathrm{x}$ & $x / 2$ & $4 x$ & $2 x$ & $x$ & $x / 2$ & $4 x$ & $2 x$ & $x$ & $x / 2$ \\
\hline \multirow[t]{5}{*}{17} & 0. & 3.95 & 4 & 3.97 & 4.04 & 3.77 & 3.91 & 3.84 & 3.96 & 3.84 & 3.95 & 3.87 & 4 \\
\hline & 3. & 0 & 0 & 0 & 5.65 & 4.25 & 5.3 & 5.39 & 6.43 & 0 & 0 & 0 & 0 \\
\hline & 6. & 0 & 0 & 0 & 6.26 & 5.9 & 7.25 & 6.9 & 7.11 & 0 & 0 & 0 & 0 \\
\hline & 12. & 0 & 0 & 0 & 7.43 & 6 & 7.27 & 6.92 & 7.14 & 0 & 0 & 0 & 0 \\
\hline & 24. & 0 & 0 & 7.16 & 8.02 & 6.94 & 6.96 & 8.01 & 8 & 0 & 0 & 4 & 5.3 \\
\hline
\end{tabular}

X: MIC value of the drug (colistin: $2 \mu \mathrm{g} / \mathrm{mL}$, sulbactam: $2 \mu \mathrm{g} / \mathrm{mL}$ ), X/2: Half of MIC value, $2 X: 2$ times MIC value, 4 X: 4 times MIC value.

most strains are resistant to many antibiotics, including carbapenem antibiotics, and do not provide adequate treatment as a result of decreased sensitivity to existing antibiotics ${ }^{[25]}$. Emergence and dissemination of infectious resistant bacteria have become a huge concern for clinicians. As a result, clinicians are seeking new treatment options. Combined antibiotic use is recommended to succeed in treatment of MDR ACB complex infections and prevent development of resistan$c e^{[26,27]}$. Kengkla et al. reported in a review article that colistin/sulbactam combination treatment was superior to, and, in terms of side effects, similar to, colistin monotherapy. They also stated this combination could be used in treatment of MDR and XDR-B infections ${ }^{[28]}$.

In the literature, the time-kill and checkerboard methods were generally used in combination or alone in a few in vitro studies on the synergic effect of colistin/sulbactam on carbapenem-resistant ACB complex isolates ${ }^{[29,30]}$. In this study, synergic effect on the same strains was studied using these two methods also.

The E-test method (gradient antibiotic strips) was used in many of the studies ${ }^{[20]}$. The reason for using the E-test method is possibly the methodological ease of use. Diffusion tests are not recommended, and the need for MIC control is emphasised in studies conducted with colistin $^{[23,32]}$. The prediffusion method was used in the studies conducted with the E-test method. No matter how standardised this method is, problems may occur with commercial gradient tests and the respective method.
The fact that colistin does not remain stable for long should also be noted. In this study, colistin lost its effect after 12 hours with the time-kill method. It is already supported by half-life and treatment doses. Another important consideration is the form of colistin to use in in vitro studies. Current guidelines emphasise colistin sulphate use should be taken as reference, and colistimethate sodium (also called colistin methylsulphonate, pentasodium colistimethan sulphate, and colistin sulphonylmethate) should not be used in in vitro studies $^{[23,32]}$.

In some synergy studies, sulbactam was not studied alone, and an ampicillin/sulbactam combination was used for the same purpose $e^{[33,34]}$. It is obvious such use of sulbactam will not be suitable for colistin/sulbactam synergy studies. Because ampicillin is also used in combination with colistin, there will only be a threefold combination.

Considering studies conducted with the time-kill method only, Lee et al. reported synergism for the colistin/sulbactam combination ${ }^{[29]}$. Pongpech et al. determined synergy against $96.7 \%$ of MDR A. baumannii of the threefold combination of meropenem/sulbactam/colistin, while they obtained 70\%, 73.3\%, and 53.3\% synergic effect for meropenem/sulbactam, meropenem/colistin, and colistin/sulbactam, respectively ${ }^{[30]}$. Laishram et al. reported $100 \%$ bactericidal effect in lower respiratory tract samples and $96 \%$ in blood samples in colistin/sulbactam combinations with the time-kill method and 36\% synergy and 64\% additive effect in colistin/sulbactam combination with the checkerboard method ${ }^{[11]}$. In this study results indicated 
$100 \%$ bactericidal effect and $88.2 \%$ synergy at 3 hours and $76.4 \%$ at 12 hours with the time-kill method in all clinical sample types. The reason for not observing synergy at 6 hours might be the colistin sensitivity in all isolates and very low MIC levels. The situation observed in two strains without synergy determined at three hours was evaluated similarly. Synergy was not determined in colistin concentrations higher than $\mathrm{MIC} / 2$, as the strains were sensitive to colistin and had low MIC values. In other words, whether sulbactam has any contribution cannot be determined, as colistin is effective against these strains, even in very low concentrations. Bactericidal effect was not determined in the studied concentrations of sulbactam alone with the time-kill method.

Thamlikitkul et al. did not determine synergy in the colistin sensitive strains in the colistin/sulbactam combination. However, they reported synergy in colistin resistant strains ${ }^{[35]}$. Deveci et al. in their study conducted with the checkerboard method obtained 50\% synergy and 50\% additive effect for the colistin/sulbactam combination in the Acinetobacter baumannii strains isolated from clinical samples (with no information reported on carbapenem sensitivity) ${ }^{[16]}$. Percin et al. reported $50 \%$ synergy in the colistin/sulbactam combination with the checkerboard method in a study they conducted on colistin-resistant Acinetobacter baumannii strains ${ }^{[17]}$. Marie et al. reported 29\% synergy and 38.9\% partial synergy in the colistin/sulbactam combination with the checkerboard method in a study they performed on MDR Acinetobacter baumannii strains ${ }^{[18]}$. Dong et al. did not report colistin/sulbactam combination synergy with the checkerboard method in MDR Acinetobacter baumannii strains ${ }^{[15]}$. In this study, in the checkerboard method, it was determined that the colistin/sulbactam combination was synergistic in 17 (85\%) strains, additive in 3 strains (15\%), and sulbactam alone (15\%) was low. Colistin was effective in all strains. Considering the results obtained with the checkerboard method in our study, a higher synergy was observed compared to other studies. As there are limited publications in this field, with more isolates and multicentred, in vivo and in vitro studies, if possible, are needed.
Anandan et al. reported $96 \%$ bactericidal effect and 68\% synergy for the colistin/sulbactam combination with the time-kill method and $16 \%$ synergy and $84 \%$ ineffective for the colistin/sulbactam combination with the checkerboard method in MDR Acinetobacter baumannii strains ${ }^{[24]}$. In the study of Yilmaz et al. (2015) in which patients undergoing VAP treatment for MDR and XDR $A$. baumannii were included, the results of colistin, sulbactam colistin and carbapenem colistin treatment were evaluated. A total of 17 patients (24.3\%) were administered colistin alone, 20 patients (28.6\%) were administered colistin and sulbactam, and 33 patients (47.1\%) were administered colistin and carbapenem. Clinical and microbiological response rates were higher in the carbapenem combination group $(63.6 \%$ and $63.6 \%$ in both) than in the sulbactam combination group, which registered $55.0 \%$ and $60.0 \%$, respectively. As a result of the study, no significant difference was found between colistin alone and combination groups regarding clinical and microbiological efficacy and mortality ${ }^{[38]}$. In the study of Kalin et al. (2014), 89 patients diagnosed with VAP were worked. Colistin was given to $58.4 \%$ of them, while colistin combined with sulbactam was given to $41.6 \%$ patients. On the 5 . day of treatment, the clinical reaction rate was $40.4 \%$ in the colistin group and $43.2 \%$ in the combined group. As a result of the treatment, the clinical response rate was $29.8 \%$ and $40 \%$, and the microbiological response rate was $72.3 \%$ and $85.7 \%$, respectively. It was reported that the clinical response and bacteriological cure rates were better in the sulbactam-colistin group, but the difference was not statistically significant ${ }^{[39]}$.

Clinical studies researching the effect of combination therapy with according to clinical-microbiological response, and mortality have been limited, and there is no consensus. In our study, we investigated the effect of colistin and sulbactam combined as in vitro. One of the limitations of our study was the inability to perform in vivo synergy tests.

In conclusion, it was determined sulbactam was solely effective on a low (15\%) MIC level against $\mathrm{ACB}$ complex strains and did not have 
a bactericidal effect, while colistin was effective on all strains. It was observed that the colistin/ sulbactam combination had a synergic effect on many of the evaluated strains using both methods (time-kill and checkerboard). Synergy studies on colistin in combination with other antibiotics should be conducted on antibiotic-resistant or high MIC strains. However, in vitro studies should be accompanied by in vivo studies. Current studies in the literature produced different results. Therefore, additional studies are needed in which a higher number of isolates and concurrency with in vivo studies are demonstrated.

\section{ETHICS COMMITTEE APPROVAL}

Approval was obtained from Sakarya University Faculty of Medicine Deanery Non-invasive Ethics Committee for our study (Decision no: 176).

\section{CONFLICT of INTEREST}

The authors declare that they have no conflict of interest.

\section{AUTHORSHIP CONTRIBUTIONS}

Conception/Design: MK

Data Acquisition: IKK, MK

Analysis/ Interpretation: HH, ÜK, İK

Writing: EPKK, İK

Final Approval: MA, MK

\section{REFERENCES}

1. Fournier PE, Richet $\mathrm{H}$. The epidemiology and control of Acinetobacter baumannii in health care facilities. Clin Infect Dis 2006;42(5):692-9.

2. Maragakis LL, Perl TM. Acinetobacter baumannii: epidemiology, antimicrobial resistance and treatment options. Clin Infect Dis 2008;46(8):1254-63.

3. Aygün G. Yoğun bakım birimlerinde antibiyotik direnç problemi ve tedavide güncel durum: Non-fermentatifler (Pseudomonas aeruginosa, Acinetobacter spp., Stenotrophomonas maltophilia). Türk Yoğun Bakım Dergisi 2007;5:25-8.

4. Bergogne-Berezin E, Towner KJ. Acinetobacter spp. as nosocomial pathogens: microbiological, clinical, and epidemiological features. Clin Microbiol Rev 1996;9(2):148-65.

5. Bahar GH, Esen N. Acinetobacter türleri ve diğer gram negatif non-fermentatif basiller. Enfeksiyon Hastalıkları ve Mikrobiyolojisi, Nobel Tip Kitabevi, İstanbul, 2008.

6. Souli M, Galani I, Giamarellou H. Emergence of extensively drug-resistant and pandrug-resistant Gram-negative bacilli in Europe. Euro Surveill 2008;13(47):pii:19045.
7. Bonomo RA, Szabo D. Mechanisms of multidrug resistance in Acinetobacter species and Pseudomonas aeruginosa. Clin Infect Dis 2006;43(2):49-56.

8. Higgins $P G$, Dammhayn C, Hackel M, Seifert H. Global spread of carbapenem resistant Acinetobacter baumannii. Journal of Antimicrob Chemother 2010;65(2):233-8.

9. Kwa A, Kasiakou SK, Tam VH Falagas ME. Polymiyxin B similarities to and differences from colistin (polymyxin E). Expert Rev Anti Infect Ther 2007;5(5):811-21.

10. Kalin G, Alp E, Akin A, Coskun R, Doganay M. Comparison of colistin and colistin/sulbactam for the treatment of multidrug resistant Acinetobacter baumannii ventilator-associated pneumonia. Infection 2014;42(1):37-42.

11. Laishram S, Anandan S, Devi BY, Elakkiya M, Priyanka B, Bhuvaneshwari $T$, et al. Determination of synergy between sulbactam, meropenem and colistin in carbapenem-resistant Klebsiella pneumoniae and Acinetobacter baumannii isolates and correlation with the molecular mechanism of resistance. J Chemother 2016;28(4):297-303.

12. Falagas ME, Kasiakou SK. Colistin: The revival of polymyxins for th of multidrug-resistant Gram-negative bacterial infection. Clin Infect Dis 2005;40(9):1333-41.

13. Cai $Y$, Chai $D$, Wang $R$, Liang B, Bai N. Colistin resistance of Acinetobacter baumannii: clinical reports, mechanisms and antimicrobial strategies. I Antimicrob Chemother 2012;67(7):1607-15.

14. Kempf M, Djouhri-Bouktab L, Brunel JM, Raoult D, Rolain JM. Synergistic activity of sulbactam combined with colistin against colistin-resistant Acinetobacter baumannii. Int J Antimicrob Agents 2012;39(2):180-1.

15. Dong $X$, Chen F, Zhang Y, Liu H, Liu Y, Ma L. In vitro activities of sitafloxacin tested alone and in combination with rifampin, colistin, sulbactam, and tigecycline against extensively drug-resistant Acinetobacter baumannii. Int / Clin Exp Med 2015;8(5):8135-40.

16. Deveci A, Coban AY, Acicbe O, Tanyel E, Yaman G, Durupinar $B$. In vitro effects of sulbactam combinations with different antibiotic groups against clinical Acinetobacter baumannii isolates. J Chemother 2013;24(5):247-52.

17. Percin D, Akyol S, Kalin G. In vitro synergism of combinations of colistin with selected antibiotics against colistin-resistant Acinetobacter baumannii. GMS Hyg Infect Control 2014;9(2):Doc14.

18. Marie MA, Krishnappa LG, Alzahrani Al, Mubaraki MA, Alyousef $A A$. A prospective evaluation of synergistic effect of sulbactam and tazobactam combination with meropenem or colistin against multidrug resistant Acinetobacter baumannii. Bosn J Basic Med Sci 2015;15(4):24-9.

19. Alada DM, Altoparlak Ü, Coşkun MV. Investigation of in vitro effects of various antibiotic combinations against Acinetobacter species. Ankem Derg 2017;31(1):23-31.

20. Çetinkol Y, Telli M, Altunçekiç Yıldırım A, Çalgın MK. Evaluation of the efficacy of colistin/sulbactam combination on carbapenem-resistant Acinetobacter baumannii strains. Mikrobiyol Bul 2016;50(3):460-5. 
21. Van Heijenoort J. Mecanismes moleculaires de la bactericidie: Beta-lactamines. In: Courvalin P, Drugeon H, Flandrois J-P, Goldstein F, eds. Bactericidie. Aspects theoriques et therapeutiques. Paris, Editions Maloine 1990; 13-22.

22. Ernest EJ, Yodoi K, Roling EE, Klepser ME. Rates and extents of antifungal activities of amphotericin B, flucytosine, fluconazole, and voriconazole against Candida lusitaniae determined by microdilution, Etest and time-kill methods. Antimicrob Agents Chemother 2002;46(2):578-81.

23. Clinical and Laboratory Standards Institute. Performance standards for antimicrobial susceptibility testing. 20. Informational Supplement. Document M100-ED28, 2018. CLSI, Wayne, PA. Available form: http://em100.edaptivedocs. info/GetDoc.aspx?doc=CLSI\%20M100\%20ED28:2018\&scope $=$ user

24. Anandan S, Jennifer SL, Pragasam AK, Abirami BS. Synergy testing between sulbactam and meropenem/colistin in MDR Acinetobacter baumannii-calcoaceticus complex isolated from ventilator associated pneumonia. J Infect Dis Ther 2016:4:299.

25. Yıldırım MI, Tuğrul HM. Assessment of efficacies of imipenem, cefoperazone-sulbactam and cefepime in rats with experimental thigh abscess model with multi-drug-resistance and susceptible Acinetobacter baumannii strains. Mikrobiyol Bul 201 1;45(3):422-9.

26. Yıldız O. Çoğul dirençli Gram-negatiflerde tedavi yaklaşımı: Acinetobacter türleri. Yoğun Bakım Dergisi 2007;7(1):1445.

27. Punpanich W, Munsrichoom A, Srisarang S, Treeratweeraphong $V$. In vitro activities of colistin and ampicillin/sulbactam against Acinetobacter baumannii. J Med Assoc Thai 2011;94(Suppl 3):95-100.

28. Kengkla K, Kongpakwattana K, Saokaew S, Apisarnthana$\operatorname{rak} A$, Chaiyakunapruk $N$. Comparative efficacy and safety of treatment options for MDR and XDR Acinetobacter baumannii infections: A systematic review and network meta-analysis. J Antimicrob Chemother 2018;73(1):22-32.

29. Lee CH, Tang YF, Su LH, Chien CC, Liu JW. Antimicrobial effects of varied combinations of meropenem, sulbactam, and colistin on a multi-drug-resistance Acinetobacter baumannii isolate that caused meningitis and bacteremia. Microb Drug Resist 2008;14(3):233-7.

30. Pongpech $P$, Amornnopparattanakul S, Panapakdee S, Fungwithaya S, Nannha P, Dhiraputra C, et al. Antibacterial activity of carbapenem based combinations againts multi-drug-resistance Acinetobacter baumannii. I Med Assoc Thai 2010;3(2):161-71.
31. Temocin F, Erdinc FS, Tulek $N$, Demirelli $M$, Ertem $G$, Kinikli $S$, et al. Synergistic effects of sulbactam in multi-drug-resistant Acinetobacter baumannii. Braz J Microbiol 2015;46(4):1119-24

32. European Committee on Antimicrobial Susceptibility Testing. Breakpoint tables for interpretation of MICs and zone diameters. EUCAST; 2018 Version 8.0.

33. Cikman A, Ceylan MR, Parlak M, Karahocagil MK, Berktas M. Evaluation of colistin-ampicillin/sulbactam combination efficacy in imipenem-resistant Acinetobacter baumannii strains. Mikrobiyol Bul 2013;47(1):147-51.

34. Yavaş S, Yetkın MA, Kayaaslan B, Baştuğ A, Aslaner H, But $A$, et al. Investigating the in vitro synergistic activities of several antibiotic combinations against carbapenem-resistant Acinetobacter baumannii isolates. Turkish I Med Sci 2016;46(3):892-6.

35. Thamlikitkul V, Tiengrim S. In vitro activity of colistin plus sulbactam against extensive-drug-resistant Acinetobacter baumannii by checkerboard method. I Med Assoc Thai 2014;97(Suppl 3):1-6.

36. Gül Y, Tümer G. Çoklu dirençli Gram-negatif mikroorganizmalara bağlı nozokomiyal pnömoni tedavisinde inhaler kolistin kullanımı. FLORA 2013;18(3):105-12.

37. Bal C.. Antibiyotik kombinasyonlarının in vitro etkinliğinin saptanması. FLORA 1999;4(4):219-29.

38. Yilmaz GR, Guven T, Guner R, Kocak Tufan Z, Izdes S, Tasyaran $M A$, et al. Colistin alone or combined with sulbactam or carbapenem against $A$. baumannii in ventilator-associated pneumonia. J Infect Dev Ctries 2015;9:476-85.

39. Kalin G, Alp E, Akin A, Coskun R, Doganay M. Comparison of colistin and colistin/sulbactam for the treatment of multidrug resistant Acinetobacter baumannii ventilator-associated pneumonia. Infection 2014;42:37-42.

\section{Address for Correspondence/Yazıșma Adresi} İmdat KILBAS

Sakarya Üniversitesi Tıp Fakültesi Tibbi Mikrobiyoloji Anabilim Dalı, Sakarya-Türkiye

E-mail: imdtklbs@gmail.com 